\title{
Energy design and experimental evaluation of an industrial burner to natural gas
}

\author{
Ph.D. Freddy J. Rojas ${ }^{1,2}$, M.Sc. Fernando Jimenez ${ }^{2}$ and B.Sc. Luis Napan ${ }^{2}$ \\ ${ }^{1}$ Research Group on Applied Environmental Control and Energy Efficiency Methodologies (GICA). \\ e-mail: fjrojas@pucp.edu.pe \\ ${ }^{2}$ Department of Mechanical Engineering. \\ Pontificia Universidad Católica del Perú. \\ Av. Universitaria 1801, San Miguel 15088 (Perú) \\ e-mail: ojimene@pucp.edu.pe, luis.napan@pucp.edu.pe
}

\begin{abstract}
This research is focused on the design and experimental evaluation of a high-power industrial burner supplied by natural gas at an operating pressure of 23 mbar, based on improving thermal efficiency with a variation in geometric parameters. The specific objectives of the work were the following: Define the calculation procedure to establish the geometric characteristics of the burner, determine the thermal efficiency define a test procedure for the tests of thermal efficiency and finally analyse the data obtained from the power, thermal efficiency, and fuel consumption of the designed burners. This investigation will be preliminarily presented for a three-part burner.
\end{abstract}

Key words. Industrial burner, thermal efficiency, geometric parameters

\section{Introduction}

In recent years, in Peru, the consumption of fossil fuels has increased to approximately $80 \%$ of the energy consumed in Peru [1]. Two of the most used fuels for cooking food, heating water, and heating are liquefied petroleum gas (LPG) and natural gas. Along with the fuel boom, the sale of industrial kitchens rose significantly. The Peruvian market today offers different types of cookers with different burners; however, the characteristics of the power delivered by the stoves through the fuels used are not specified. The industrial kitchens that are offered by the Peruvian market have low thermal efficiency $40 \%$ or less efficiency, and this is not indicated in their technical data, this can be seen in the yellow color of the flame due to the bad combustion that forms and as a result consumes more fuel than it should [2].

Indoor environmental quality is one of the most important aspects of health since, if not controlled, these could negatively affect people's well-being. Some immediate health effects can appear shortly after a single exposure or repeated exposures to a contaminant. These include irritation of the eyes, nose, and throat, headaches, dizziness, and fatigue. Such immediate effects are usually short-term and treatable. Sometimes treatment is simply to remove the person's exposure to the source of the contamination if it can be identified. Soon after exposure to some indoor air pollutants, the symptoms of some diseases such as asthma may appear, worsen, or worsen. For this reason, it is important to pay attention to when and where symptoms occur. Some effects may be worsened by an inadequate supply of outside air coming indoors or by the prevailing heating, cooling, or humidity conditions inside. In contrast, long-term health effects can appear years after exposure or only after prolonged or repeated periods of exposure [3]. Air pollution is one of the most important problems today, some of the aspects that most influence air pollution are global warming, ozone depletion, and acid rain. In addition to this, indoor air pollution such as levels of particulate matter and ozone tends to lead to adverse effects on people's health [4]. The environmental quality of indoor air requires adequate attention due to the long periods of exposure of people, which include the elderly, who are the most vulnerable to respiratory diseases [5]. Environmental pollution is one of the most dangerous risks, it represents around 5 million deaths from various respiratory diseases caused by environmental pollution [6]. Gas stove burners generate an effect on environmental pollution due to the combustion that is generated. Concentrations of carbon monoxide (CO), nitrogen dioxide $\left(\mathrm{NO}_{2}\right)$, and formaldehyde $(\mathrm{HCHO})$ are emitted, the latter occurs when combustion is bad [7].

Several researchers have sought ways to improve the efficiency of industrial kitchens, because of their research they have discovered that various factors can directly affect the combustion of the air-fuel mixture. An investigation was conducted on the KB-5 high-pressure gas burners that are frequently used in Thailand. The research aimed to study how the variation of four significant parameters affected the thermal efficiency: the angle of the external and internal ports, and the number of external and internal ports of the gas burners. Thermal efficiency was tested concerning standard industrial stoves in homes (TIS 2312-2549). The results showed that increasing the external port angle increased thermal efficiency by $13 \%$, increasing the number of external ports 
increased thermal efficiency by $5 \%$, and increasing the number of internal ports increased efficiency by $7 \%$. thermal. Increasing the inner port angle had less effect on thermal efficiency. As a conclusion, it was obtained that for greater thermal efficiency, the number of external and internal ports must be increased, as well as the angle of the external port. This design would improve efficiency compared to the factory design [8]. Other research in India aimed to study various works that have focused on improving the efficiency and gas emission characteristics of LPG-fuelled stoves. The parameters for this study were: performance, efficiency, and gas emission characteristics were considered. The research focused on LPG stoves, although a variant in the form of biogas was also studied. As a result of the investigation, it was found that to improve thermal efficiency, the specifications, design, and burner material must be improved; air preheating can be considered as an influencing factor in the efficiency. By modifying the design of the burner nozzle, higher efficiency can be obtained and, in this way, drastically reduce $\mathrm{CO}$ and $\mathrm{NOx}$ emissions. Finally, it was also found that the selection of the material plays an important role in the performance of the stove, the most efficient burners found were cast iron [9].

For this project, an industrial burner with three burners with $3.5 \mathrm{~kW}$ of power in parallel was designed for the test. This is the initial part of a bigger project where there will be more burner designs consisting of two burners in parallel and another with a single head. For the design of the burner, the concepts of thermodynamics and fluid mechanics were considered to obtain the value of the parameters to be varied. For burner designs, tests will be carried out to analyze thermal efficiency. The experimental part was used as a methodology to determine the thermal efficiency of the prototype kitchen through the designed and manufactured burners.

\section{Methodology}

The tests will have as reference the Ecuadorian technical standard NTE INEN 2259: 2013 [10] to determine the efficiency of the burners, these tests will be carried out in the test bench of the "gaseous fuel combustion laboratory" of the Mechanical Engineering section of the Pontificia Universidad Católica del Perú.

The burner developed must be subjected to experimental tests varying different parameters and conditions to determine the efficiency and evaluate the quality of the airfuel gas mixture generated in the combustion process. After that, the effects generated by the different variations can be evaluated. It is expected to obtain an improvement in the use of fuel when generating combustion due to the previous investigations that were carried out before this project. As part of this project, research work was carried out on what are the geometric parameters or variation of conditions with which an increase in thermal efficiency is generated and in turn a decrease in the emissions produced, as a result, what was already mentioned in the Previous design of the burners, but in addition to this, it was obtained that there are also improvements when varying the loading height (which represents the distance between the container to be used and the burner itself), the variation of the different diameters of the injector and its distance to the mixer. That is why it will use all these variations and it will see with the results of the tests which are the most feasible to generate an improvement in thermal efficiency, which is what is sought as the main objective of the project.

\section{A. Thermal efficiency tests}

For the thermal efficiency tests, as already mentioned in the part that presented the project methodology, the Ecuadorian standard NTE INEN 2259: 2013 was used. For which the use of a type $\mathrm{K}$ thermocouple, a stopwatch, and a gas flow meter was required. Next, it can observe using Fig. 1 how the test bench was arranged.

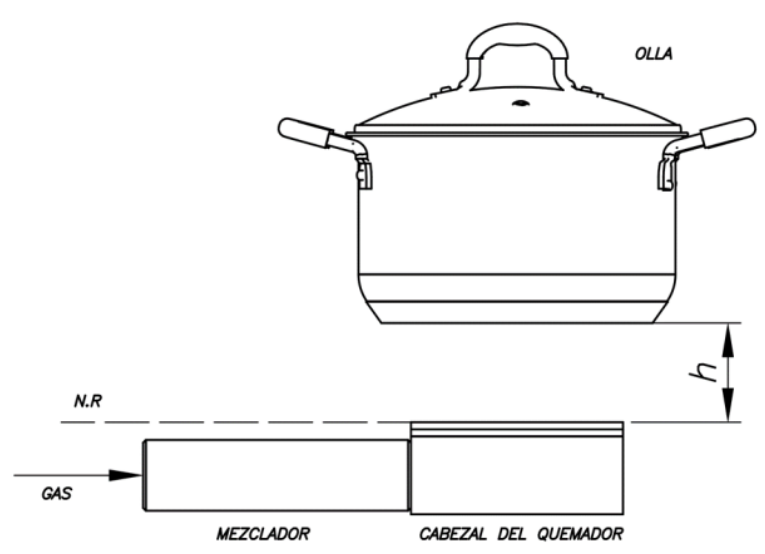

Fig.1. Scheme of tests carried out on the test bench.

Additionally, the tests carried out will have as a fixed parameter the distance between the injector and the mixer inlet, said distance being $0 \mathrm{~mm}$, that is, the injector will be flush with the mixer inlet. This distance was chosen because it was observed that there was correct air entrainment, therefore, better combustion was obtained. On the other hand, preliminary tests will also be done by varying the distance from the injector to the mixer. To calculate the thermal efficiency (ec. 1) and power of the burners (ec. 2), the following equations are given by the NTE INEN 2259: 2013.

$$
\eta=m_{a} \times C_{w} \times \frac{T_{f}-T_{i}}{V_{g} \times P C I} \times 100
$$

Where:

$\eta=$ Thermal efficiency $(\%)$

$m_{a}=$ Mass of water introduced into the container $(\mathrm{kg})$

$C_{w}=$ Specific heat of water $\left(\mathrm{kJ} / \mathrm{kg} .{ }^{\circ} \mathrm{C}\right)$

$T_{i}=$ Initial water temperature $\left({ }^{\circ} \mathrm{C}\right)$

$T_{f}=$ Final water temperature $\left({ }^{\circ} \mathrm{C}\right)$

$V_{g}=$ volume of gas consumed $\left(\mathrm{m}^{3}\right)$

$P C I=$ Lower calorific value of gas $\left(\mathrm{kJ} / \mathrm{m}^{3}\right)$

$$
\mathrm{P}=\dot{\mathrm{V}}_{\mathrm{g}} \times \mathrm{PCI}
$$

Where:

$P=$ Power $(\mathrm{kW})$ 
$\dot{\mathrm{V}}_{\mathrm{g}}=$ Flow of gas consumed $\left(\mathrm{m}^{3} / \mathrm{s}\right)$

$\mathrm{PCI}=$ Lower calorific value of gas $\left(\mathrm{kJ} / \mathrm{m}^{3}\right)$

To calculate the flow of gas in the tests, a flow meter will be used and will be installed on the test bench.

\section{B. Materials}

To take measurements of the tests carried out on the manufactured burner, there was a test bench like the one shown Fig. 2 (three-part burner):

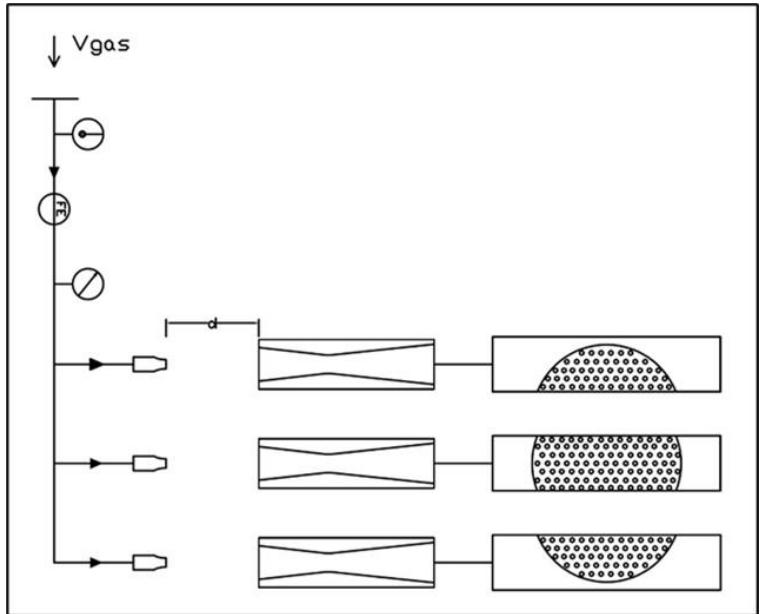

Fig.2. Scheme of the test bench in the laboratory.

The instruments were mounted on the gas line in such a way that it is possible to regulate and measure the flow of the combustible gases to have greater control over the design parameters and operating conditions in which the experimental tests will be carried out, in addition to there is a continuous fuel flow input throughout the operation. In the fig. 3 you can see a diagram of the test bench of the "gaseous fuel combustion laboratory" of the Mechanical Engineering section of the Pontificia Universidad Católica del Perú.

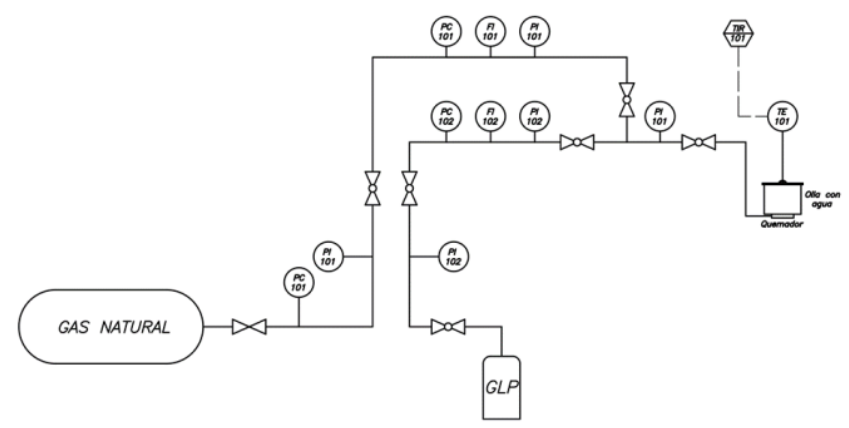

Fig.3. Fuel gas measurement system and distribution.

For the thermal efficiency test, a $32 \mathrm{~cm}$ diameter pot will be used that must contain $11.4 \mathrm{~kg}$ of water because it is a highpower burner and is what the Ecuadorian standard NTE INEN 2259: 2013 recommends (Table I).
Table I. - Values of the variables to be used in the tests

\begin{tabular}{|l|c|c|}
\hline \multicolumn{1}{|c|}{ VARIABLE } & UNITY & VALUE \\
\hline Water mass & $\mathrm{kg}$ & 11.4 \\
\hline Specific heat of water & $\mathrm{kJ} / \mathrm{kg} \cdot{ }^{\circ} \mathrm{C}$ & 4.186 \\
\hline Initial water temperature & ${ }^{\circ} \mathrm{C}$ & 27 \\
\hline Final water temperature & ${ }^{\circ} \mathrm{C}$ & 90 \\
\hline $\begin{array}{l}\text { The lower calorific value } \\
\text { of natural gas (Camisea } \\
\text { project) }\end{array}$ & $\mathrm{kJ} / \mathrm{m}^{3}$ & 36040 \\
\hline
\end{tabular}

Initially, tests were carried out for natural gas. For data collection, this equipment was used: Vantage Pro-2 plus meteorological equipment to measure air properties, thermocouples, manometers to measure gas properties. The characteristics of meteorological equipment can be seen in Table II:

Table II. - Vantage pro-2 plus measurement features

\begin{tabular}{|c|c|}
\hline RANGE & $\begin{array}{c}\text { NOMINAL } \\
\text { ACCURACY }\end{array}$ \\
\hline $540-1100 \mathrm{hPa}$ & $1 \mathrm{hPa}$ \\
\hline $0-100 \%$ & $5 \% \mathrm{HR}$ \\
\hline $0-60^{\circ} \mathrm{C}$ & $0.5^{\circ} \mathrm{C}$ \\
\hline$-40-65^{\circ} \mathrm{C}$ & $0.5^{\circ} \mathrm{C}$ \\
\hline $1-80 \mathrm{~m} / \mathrm{s}$ & $1 \mathrm{~m} / \mathrm{s}$ \\
\hline
\end{tabular}

\section{Burner design}

\section{A. Injector design}

To determine the injector design, the gas flow that will pass through the injector orifice must first be determined to operate at the required conditions. It should be noted that the design will be made to operate at a power of 3.5 $\mathrm{kW}$.

$$
\dot{\mathrm{m}}_{\mathrm{g}}=\frac{\mathrm{P}_{\mathrm{q}}}{\mathrm{PCI}}
$$

Where:

$\dot{\mathrm{m}}_{\mathrm{g}}=$ Mass flow of fuel gas $(\mathrm{kg} / \mathrm{s})$

$\mathrm{P}_{\mathrm{q}}=$ Power required in the burner $(\mathrm{kW})$

$\mathrm{PCI}=$ Lower calorific value of gas $(\mathrm{kJ} / \mathrm{kg})$

$\dot{\mathrm{m}}_{\mathrm{g}}=7.227 \times 10^{-5} \mathrm{~kg} / \mathrm{s}$

For the development of the injector design calculations, it was made based on the paper "Diseño y Evaluación de Mezcladores de un Quemador Doméstico usando Gas Licuado de Petróleo" [11].

$$
A_{e}=\frac{m_{g}}{C_{d} \times \rho_{e} \times M_{e} \times c_{e}}
$$

$A_{e}=1,317 \mathrm{~mm}^{2}$

With these results, it is determined that for the tests carried out with natural gas one of $1,295 \mathrm{~mm}$. Injector with this 
diameter value cannot be found on the market, therefore, an approximate value will be used:

An injector with a diameter of $1.3 \mathrm{~mm}$ will be used.

\section{B. Mixer design}

For the design of the mixer, the recommendations given by the author David Fulford [12] will be taken into account.

Natural gas is composed of $88.54 \%$ methane, $10.32 \%$ ethane, $0.02 \%$ propane, $0.54 \%$ nitrogen and $0.58 \%$ carbon dioxide, the stoichiometric mixture with $10 \%$ excess air being the following:

$$
\begin{aligned}
& \left(0.8854 \mathrm{CH}_{4}+0.1032 \mathrm{C}_{2} \mathrm{H}_{6}+0.0002 \mathrm{C}_{3} \mathrm{H}_{8}+\right. \\
& \left.0.0054 \mathrm{~N}_{2}+0.0058 \mathrm{CO}_{2}\right)+2.346\left(\mathrm{O}_{2}+3.76 \mathrm{~N}_{2}\right) \rightarrow \\
& 1.0982 \mathrm{CO}_{2}+2.0812 \mathrm{H}_{2} \mathrm{O}+8.826 \mathrm{~N}_{2}+1.2478 \mathrm{O}_{2}
\end{aligned}
$$

In this way, the air-fuel gas ratio will be as follows:

$$
\mathrm{RAC}_{\mathrm{v}}=\frac{2.346 \times 4.76 \times 24.8}{1 \times 24.8}=11.168
$$

The amount of primary air that will be used in the mixture will be $50 \%$ of the total air required, as recommended in the paper "Biogas Stove Design", prepared by Dr. David Fulford. This recommendation will be taken into account in both cases. Thus, the drag relationship will be defined by:

$$
\mathrm{r}_{a r}=0.5 \times \mathrm{RAC}_{\mathrm{v}}
$$

$\mathrm{r}_{a r}=5.58$

The diameter of the throat of the Venturi-type mixer $\left(D_{t}\right)$ will be determined by the Prigg formula, [13]:

$$
\mathrm{D}_{\mathrm{t}}=\left(\frac{\mathrm{r}_{\mathrm{ar}}}{\sqrt{\mathrm{s}}}+1\right) \times \mathrm{d}_{\mathrm{i}}
$$

Where:

$\mathrm{D}_{\mathrm{t}}=$ Mixer throat diameter $(\mathrm{mm})$

$\mathrm{s}=$ Relative density of fuel gas

$\mathrm{r}_{\mathrm{ar}}=$ Drag ratio

$\mathrm{d}_{\mathrm{i}}=$ Selected injector diameter $(\mathrm{mm})$

Taking another recommendation from the article "Design of biogas stoves", the length of the venturi will be found with the following formula:

$$
\mathrm{L}_{\mathrm{t}}=6 \times \mathrm{D}_{\mathrm{t}}
$$

While to determine the geometry of the diffuser, a book recommendation will be taken into account, which indicates that the diffuser must have an angle between $5^{\circ}$ to $8^{\circ}$ concerning the central axis [13].

$$
\mathrm{L}_{\mathrm{d}}=12 \times \mathrm{D}_{\mathrm{t}}
$$

Is obtained:

$\mathrm{D}_{\mathrm{t}}=11.77 \mathrm{~mm}$

$\mathrm{L}_{\mathrm{t}}=70.64 \mathrm{~mm}$
$L_{d}=141.28 \mathrm{~mm}$

The model has a throat diameter of $11.77 \mathrm{~mm}$, the length of the inlet section of the mixer called Venturi has a length of $70.64 \mathrm{~mm}$, while the divergent section called diffuser has a length of $141.28 \mathrm{~mm}$. An angle of $7^{\circ}$ concerning the central axis will be used for the design of the section called Venturi, while an angle of $5^{\circ}$ concerning the central axis will be used for the design of the section called a diffuser.

\section{Burner head}

Following the recommendation of the book "natural gas engineering and Safety Challenges" for equation 9, which derives from the Prigg formula, friction losses and the discharge coefficient are taken into account. The resulting diameter is taken as if there was only one port for the flame outlet [13].

$$
\mathrm{D}_{\mathrm{p}}=\frac{\mathrm{D}_{\mathrm{t}}}{\sqrt{0,7}}
$$

Where:

$D_{p}=$ Flame port diameter $(\mathrm{mm})$

The total area of the flame port is found, considering it as a single hole:

$$
A_{p}=\frac{\pi \times D_{p}^{2}}{4}
$$

Where:

$A_{p}=$ Flame port area $\left(\mathrm{mm}^{2}\right)$

To calculate the number of holes, the port diameter of the hole will be proposed to have a value of $1.5 \mathrm{~mm}$ :

$$
\mathrm{N}_{\mathrm{p}}=\frac{4 \times \mathrm{A}_{\mathrm{p}}}{\pi \times \mathrm{d}_{\mathrm{p}}^{2}}
$$

Where:

$\mathrm{N}_{\mathrm{p}}=$ Number of ports on the burner head

$\mathrm{d}_{\mathrm{p}}=$ Burner head port diameter $(\mathrm{mm})$

$\mathrm{D}_{\mathrm{p}}=16.12 \mathrm{~mm}$

$A_{p}=163.223 \mathrm{~mm}^{2}$

$\mathrm{N}_{\mathrm{p}}=92$

\section{Results}

As previously mentioned, different tests were carried out where the loading height and the diameter of the injector were varied to see their effect on thermal efficiency. We see in Table III that the injector diameter that was used was $1 \mathrm{~mm}, 1.1 \mathrm{~mm}, 1.2 \mathrm{~mm}, 1.3 \mathrm{~mm}$, and $1.4 \mathrm{~mm}$. For the tests, the NTE INEN 2259: 2013 was used, with which values of approximately $30 \%$ of thermal efficiency were obtained, this is because there is an inversely proportional 
relationship to the burner power. According to NTE INEN 2259: 2013 the temperature must start at $27^{\circ} \mathrm{C}$ to end at $90^{\circ} \mathrm{C}$. The higher the burner power, the lower its thermal efficiency. Is important to mention that exists a distance between the injector and mixer, this distance was varied in different cases to evaluate the effect in the thermal efficiency but table III just shows $20 \mathrm{~mm}$ of distance preliminarily.

Table III. Preliminary test results.

\begin{tabular}{|c|c|c|c|c|c|c|}
\hline Test & $\begin{array}{c}\mathrm{h} \\
(\mathrm{mm})\end{array}$ & $\begin{array}{c}\mathrm{Di} \\
(\mathrm{mm})\end{array}$ & $\mathrm{t}(\mathrm{s})$ & $\begin{array}{c}\mathrm{V} \\
(\mathrm{LPM})\end{array}$ & $\mathrm{\eta}(\%)$ & $\mathrm{P}(\mathrm{kW})$ \\
\hline 1 & 40 & 1.0 & 1326.4 & 12.90 & 29.72 & 7.7486 \\
\hline 2 & 40 & 1.1 & 1370.2 & 15.44 & 25.54 & 9.2743 \\
\hline 3 & 40 & 1.2 & 1062.3 & 17.35 & 27.16 & 10.4216 \\
\hline 4 & 40 & 1.3 & 879.8 & 17.52 & 31.96 & 10.5237 \\
\hline 5 & 40 & 1.4 & 859.1 & 19.35 & 29.63 & 11.6229 \\
\hline 6 & 30 & 1.4 & 875.0 & 19.35 & 29.09 & 11.6229 \\
\hline 7 & 30 & 1.3 & 946.6 & 17.52 & 30.18 & 10.5237 \\
\hline 8 & 30 & 1.2 & 959.7 & 17.52 & 29.77 & 10.5237 \\
\hline
\end{tabular}

Where:

$\mathrm{h}=$ Loading height $(\mathrm{mm})$

$\mathrm{Di}=$ Injector diameter $(\mathrm{mm})$

$\mathrm{t}=$ Time between initial and final temperature (s)

$\mathrm{V}=$ Volumetric gas flow (LPM)

$\eta=$ thermal efficiency $(\%)$

$\mathrm{P}=$ Burner power $(\mathrm{kW})$

In the Fig. 3 it can observe the variation of the thermal efficiency changing the value of the loading height between 30 and $40 \mathrm{~mm}$ each one. The loading height is the distance between the pot and the burner

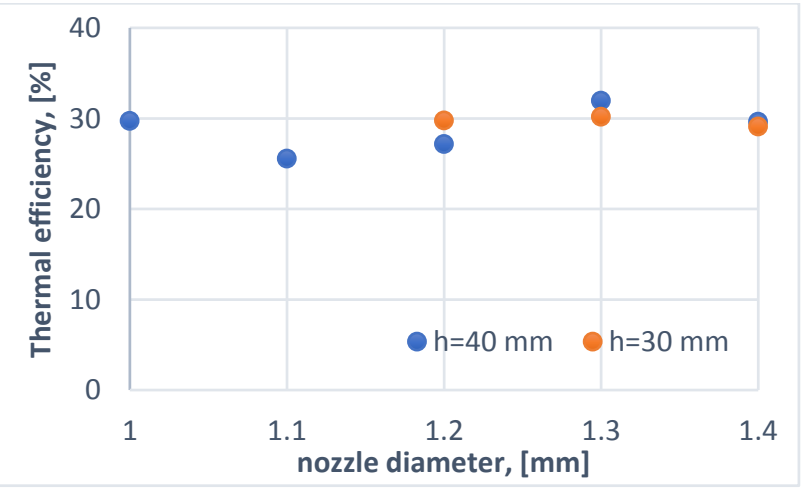

Fig. 3. Thermal efficiency vs injector diameter

\section{Conclusion}

As you can see in table III, there is a relationship between thermal efficiency and Burner power. The higher the burner power, the lower its thermal efficiency. That fact is important because if we want to increase thermal efficiency, it is necessary to work with cooking burners that have lower power. As a result of that, the efficiency would be higher. For domestic use is recommended to use the fast burner that power is between 2.09 to $3.14 \mathrm{~kW}$. With higher efficiency, we can obtain lower gas emissions and better combustion because the air-fuel mixture will be the best. About the conditions of the test, the diameter of the pot was $32 \mathrm{~cm}$. As you can see in the Fig. 3. The thermal efficiency is more constant when the loading height is $30 \mathrm{~mm}$. Also, the thermal efficiency is more in $2 \%$.

\section{Acknowledgment}

We thank to "DIRECCION DE GESTION DE LA INVESTIGACION (DGI)" that through Competitive Basic and Applied Research Projects ID707-DGI of Pontificia Universidad Católica del Peru funded the research.

\section{References}

[1] Agencia Internacional de la Energía, "Consumo de energía procedente de combustibles fósiles (\% del total)." 2014, [Online]. Available:

https://datos.bancomundial.org/indicador/EG.USE.CO MM.FO.ZS?end $=2015 \&$ start $=1960 \&$ view $=$ chart .

[2] F. J. Rojas, F. O. Jiménez, and J. Soto, “Análisis Teórico y Experimental de la Potencia, Eficiencia Térmica y Emisiones de Cocinas Industriales que usan Gas Licuado de Petróleo," Inf. tecnológica, vol. 30, no. 4, pp. 301-310, 2019, doi: 10.4067/s071807642019000400301.

[3] F. V. Marcos and I. G. Pulgarín, "Calidad ambiental interior: Bienestar, confort y salud," Rev. Esp. Salud Publica, vol. 79, no. 2, pp. 243-251, 2005, doi: 10.1590/s1135-57272005000200011.

[4] P. J. Landrigan, "Air pollution and health," Lancet Public Heal., vol. 2, no. 1, pp. e4-e5, 2017, doi: 10.1016/S2468-2667(16)30023-8.

[5] M. Abtahi et al., "The concentration of BTEX in the air of Tehran: A systematic review-meta analysis and risk assessment," Int. J. Environ. Res. Public Health, vol. 15, no. 9, 2018, doi: 10.3390/ijerph15091837.

[6] Global Burden of Disease Collaborative Network, "Global Burden of Disease Study 2017 (GBD 2017) Results. Institute for Health Metrics and Evaluation (IHME)." Seattle, United States, 2018, [Online]. Available: http://ghdx.healthdata.org/gbd-results-tool.

[7] J. M. Logue, N. E. Klepeis, A. B. Lobscheid, and B. C. Singer, "Pollutant exposures from natural gas cooking burners: A simulation-based assessment for Southern California," Environ. Health Perspect., vol. 122, no. 1, pp. 43-50, 2014, doi: 10.1289/ehp.1306673.

[8] P. Aroonjarattham, "The parametric studied of high pressure gas burner affect thermal efficiency," Eng. J., vol. 20 , no. 3, pp. 33-48, 2016, doi:

10.4186/ej.2016.20.3.33.

[9] D. Dahiya, R. Singh Lather, and P. Bhatia, "Improvement of the Domestic LPG Cooking Stoves: A Review," Indian J. Sci. Technol., vol. 9, no. S1, pp. 1-8, 2016, doi: 10.17485/ijst/2016/v9is1/105856.

[10] Instituto Ecuatoriano de Normalización, "NORMA TÉCNICA ECUATORIANA NTE INEN 2259:2013 Primera revisión ARTEFACTOS DE USO DOMESTICO PARA COCINAR, REQUISITOS E INSPECCIÓN." Quito, 2013.

[11] F. J. Rojas, F. O. Jiménez Ugarte, and J. A. Álvarez, "Diseño y Evaluación de Mezcladores de un Quemador Doméstico usando Gas Licuado de Petróleo," Inf. Tecnol., vol. 28, no. 5, pp. 191-214, 
2017, doi: 10.4067/s0718-07642017000500019.

[12] D. Fulford, "Biogas Stove Design," Biomass, no.

August, pp. 1-21, 1996.

[13] G. G. Nasr and N. E. Connor, Natural Gas Engineering and Safety Challenges. 2014. 